U. S. GEOLOGICAL SURVEY Ficld Library

Albuquerque, New Mexico

\title{
Proposed Investigations of the Southeastern Monazite Deposits
}

\section{Trace Elements Memorandum Report 21}

UNITED STATES DEPARTMENT OF THE INTERIOR GEOLOGICAL SURVEY 


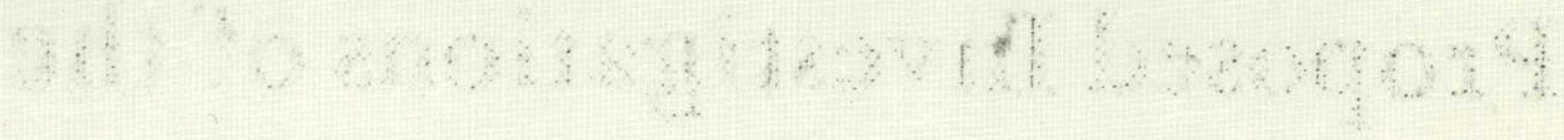

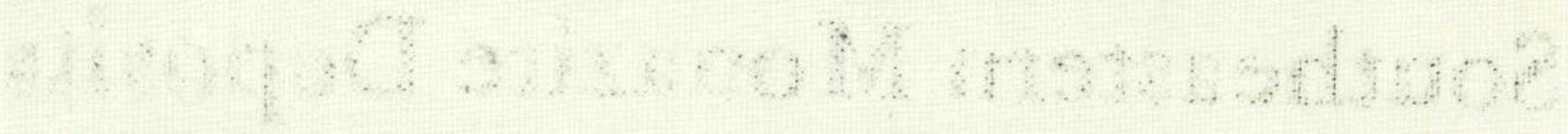


OFFICIAL USE ONLY

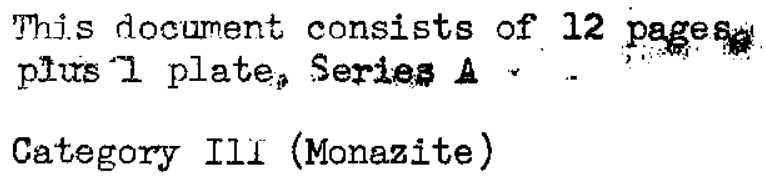

\section{UNITED STATES DEPARTMENT OF THE INTERIOR GEOLOGICAL SURVEY}

\section{PROPOSED INVESTIGATIONS OF THE SOUTHEASTERN \\ MONAZITE DEPOSITS}

By

W. C. Overstreet, V. E. McKelvey, and F. N. Houser

June $195 ?$

Trace Elements Memorandum Report 21

OFFICIAI USE ONLY 


\section{OFFICIAL USE ONLY}

\section{2}

USGS - TEM Report 21

The distribution (Series A) of this report is as follows:

3 copies ..... AEC, Washingtor (J. C. Johnson)

8 copies . . AEC, New York (P. L. Merritt)

1 copy ...... AEC, Denver, Colo. (C. C. Towle, Jr.)

I copy ..... AEC, Spokane, Wash. (E. E. Thurlow)

1 copy ..... AEC, Grand Junction, CoIo. (T. W. Oster)

10 copies. - . USGS, Washington (Mineral Deposits Branch)

I copy .... USGS, Washirgton (Geochemistry and Petrology Branch)

1 copy ..... USGS, Washington (Geophysics Branch)

1 copy ..... USGS, Washington (Fuels Branch)

1 copy ..... USGS, Washington (Alaskan Branch)

I copy ...... USGS, Washington (V. E. McKelvey)

1 copy ..... USGGS, Denver, Colo. (L. R. Page)

1 copy ...... USGS, Denver, Colo. (J.Fred Smith, Jr.)

I copy ..... Usas, Grand Junction, Colo. (R. P. Fischer)

1 copy ..... USGS, Spokane, Wash. (A. E. Weissenborn)

1 copy ..... USGS, Plant City, Fla. (J.B. Cathcart)

4 copies .... USGS, Washington (TEPCO)

(Including master copy) 


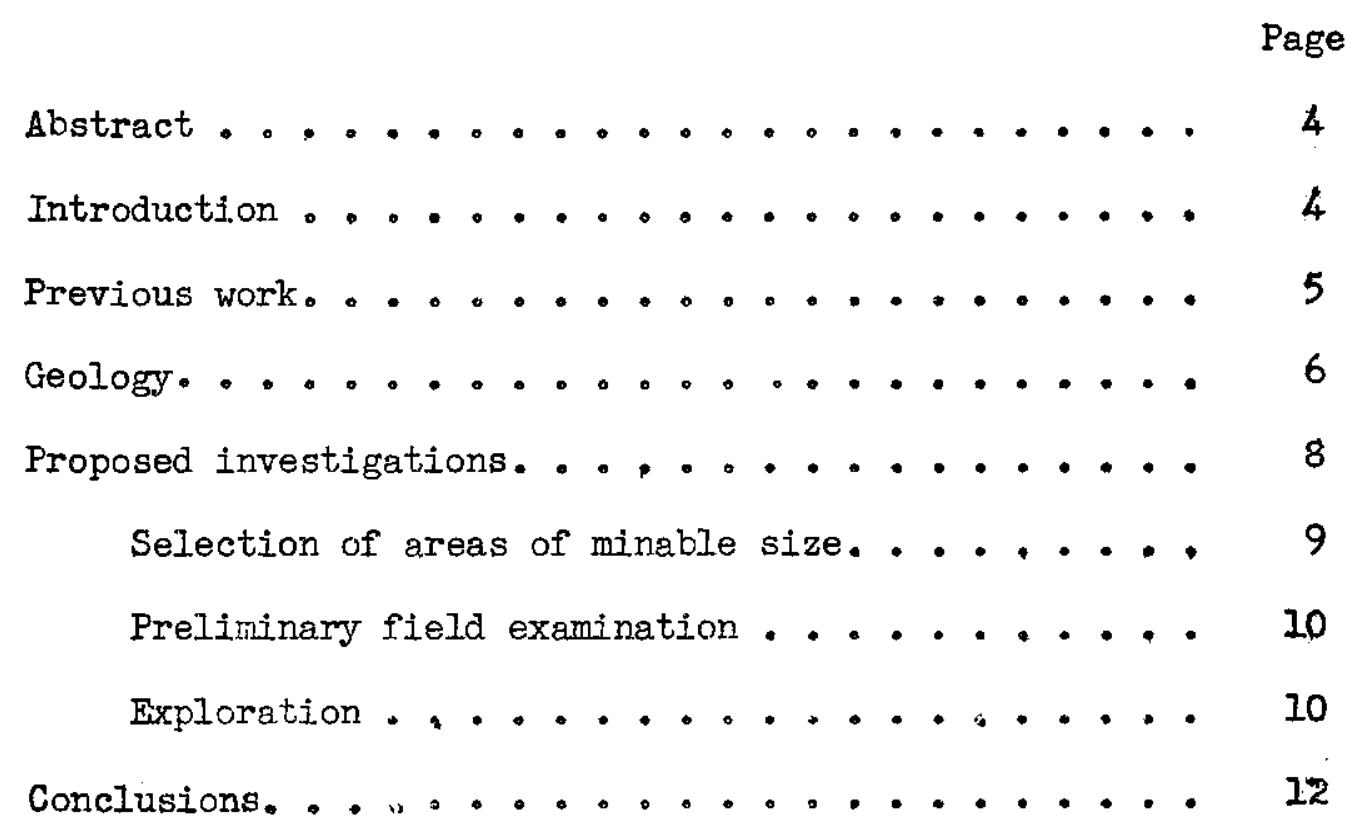

IILUSTRATIONS

Plate 1. Monazite belts of the Southeastern Atlantitio states................ In envelope 


\section{OFFICIAL USE OILY}

4.

PROPOSED TIVESTIGATIONS OF THE SOUTHEASTERN MONAZITE DEPOSITS

By

W. C. Overstreet, V. E. MoKeIvey, and F. N. Houser

ABSTRACT

The U. S. Geological Survey plans to search for and appraise monazite placer deposits of the western monazite belt in North Carolina, South Carolina, Georgia, and Virginia. The Survey will select the deposits to be explored by drilling, select the interval and extent of samples, analyze the samples obtained, and estimate reserves. It is hoped that the U.S. Bureau of Mines will be responsible for all the engineering aspects of the drilling, including the surveying of the hole locations and sampling, and for the economic or engineering appraisal of the individual deposits.

\section{INTRODUCTION}

Because there is a possibility that fissionable $U^{233}$ can be produced from $\mathrm{Th}^{232}$ by a breeder reaction similar to that by which it may be possible to producc $\mathrm{Pu}^{239}$ from $\mathrm{U}^{238} \mathrm{~J}$, thorium may eventually beSeaborg, G. T., The transuranium elements and nuclear energy:
Nieuwland lectures (University of Notre Dame) vol. II, p. 16, 1947. come a source of $\mathrm{U}^{233}$. The possible domestic sources of monazitethe main ore mineral of thorium-therefore require investigation. OFFICIAL USE ONLY 
Consequently, the Survey plans to resume its investigations of the monazite-bearing alluvial deposits of the Southeast, with the added cooperation of the Bureau of Mines, if possible. Plans for these investigations are sumarized in the following pages.

\section{PREV IOUS WORK}

The U. S. Geological Survey has been studying the monazite-bearing deposits of the Southeast from 1945 to the present (June 1951). During part of that time funds were furnished by the U. S. Atomic Energy Commision for the work on monazite. These investigations were continued by the Survey after the Commission support was withdrawn at the erd of fiscal year 1949. The work undertaken thus far has consisted of geologic mapping of the Shelby quadrangle, North Carolina (one of the important monazite areas), and reconnaissance sampling of alluvial deposits and saprolite (weathered bedrock). The sampling has led to the definition of two monazite-bearing belts which are the source of the placer monazite. _ Samples from all the Pleistocene formations and

J Mertif. J. B., Jr., Monazite in the southeastern states: U. S. Geo1. Survey Trace Hlements Memorandum Rept. 248, 1951. (A more comprehensive report on the same subject is in preparation).

some of the Tertiary formations of South Carolina and southeastern Georgia have been analyzed for heary minerals. Although the monazite content was $I$ to 3 percent of the heavy minerals, economically minable 


\section{OFFICIAL USE ONLY}

\section{6}

deposits of heavy minerals were not found in these formations $J$.

$\triangle$ Mertie, Jo $\mathrm{B}_{0}$, Jro, Heavy minerals in the Pleistocene terraces of South Carolina and Georgia: U. S. Geol. Survey Trace Elements Memorandum Rept. 23. (In preparation).

\section{GEOLOGY}

Most of the monazite placer deposits of Virginia, North Carolina, South Carolina, and Georgia were derived from two belts of highly weathered igneous and metamorphic rocks $/ 0$ (PIate 1.) Within these

$\checkmark$ Mertie, J。B, Jro, op. clit, U。S。Geol。Survey Trace Elements Memorandum Rept。248.

two belts lie the chief source rocks of monazite in the southeast, but not all rocks in the belts are monazite-bearing; these rocks may be monazite-bearing to various degrees, or free of monazite.

These belts roughly paraliel the Atlantic Coast and have a combined length of at least 625 miles. The eastern belt, which is the narrower of the two, stretches southwestward from Fredericksburg, Va. to about 20 miles south of Raleigh, $N_{0} \sigma_{0}$, where it passes beneath the Coastal Plain sedjments of Tertiary and Quaternary age. A possible extension of this belt into the crystalline rocks of Maryland will be investigated in view of some analyses reported by Robinson and Edgington $/$.

/ Robinson, W。 O.g and Edgington, Glen, Minor elements in plants, and some accumulator plants: Soil science, vol. 60, no. 1, pp. 21-24, 1945. 


\section{QFFICIAT, USE ONLY}

5

The more important western belt of monazite-bearing bedrock has been traced from a point northwest of Danville, Va, a distance of about 400 miles to the vicinity of La Grange, Ga. It is about 35 miles wide at Shelby, $N$. C. $y$ and it narrows northeastward into Virginia and southwestward into Georgia.

Southeastern monazite placer deposits of possible commercial value will be found in, or close to these belts of monazite-bearing bedrock. Mertie / found a mean minimum value of 8.4 pounds of

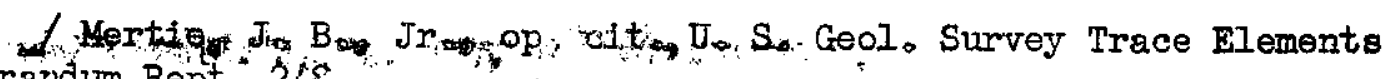
Memorandum Rept: $24 \mathrm{~s}$.

monazite per cubic yard in gravels in the headwater stretches of streams. In the 52 samples tested the monazite contained an average of 5.7 percent $\mathrm{ThO}_{2}$ and 0.38 percent $\mathrm{U}_{3} \mathrm{O}_{8}$.

The volume of alluvium in the headwater reaches in areas of monazite-bearing rock is too small to be minable on a large scale. The cubic yardage of placers along trunk streams is greater but the tenor of the monazite is less, because of the increased addition of sand and gravel from tributaries draining areas barren of monazite. The search will not be in the trunk streams (as the Broad River or Catawba River) or in the secondary drainage immediately tributary to the trurk streams (as the First Broad River and South Fork River), but will be in the most broadly alluviated valleys tributary to the secondary rivers. Knob Creek in Cleveland County, N. C., is an example of the portion of the drainage net

\section{OFFICIAL USE ONLY}




\section{OFFICIR工 USE ONLY}

that will be studied. Intermediate stretches of some streams in the monezite-bearing bedrock belt may contain as much as 5 pounds of monazite per cubic yard in moderate volume and it is these areas that will be most favorable for monazite production.

Although the placer deposits of commercial size and tenor would be minable for monazite as the main product, other heavy minerals such as xenotime, ircon, ilmenite, garnet, and sillimanite probably might be recoverable as byproducts. The proportion and kind of these accessory heavy minerals will vary widely from place to place along the belt. Even if they are not recovered their relative abundance may dictate variations in beneficiating heavies from separate districts.

\section{PROPOSED INVESTIGATIONS}

The investigations proposed by the Survey focus on the western monazite belt in North Carolina, South Carolina, Georgia, and Virginia. The objectives of the work are to locate and appraise monazite placers of sufficient size to permit mining by modern earthmoving equipment. The field work consists of three phases, (I) som lection of areas of elluvitum large enough to be minable, (2) preliminary field examination of the selected areas, and (3) exploration of some of those that promise to be of minable tenor. 


\section{OFF ICIAI USE ONLY}

\section{9}

Selection of areas of minable size

Areas of alluvium of sufficient size to warrant investigation will be selected by examination of aerial photographs of the western monazite belt. Such selected areas of alluvium must be situated far enough upstream to include small drainage basins potentially underlain largely by monazite-bearing rocks. This exanination of photographs will delimit the alluviated areas, but will give scant data on bedrock geology. It will be completed for one state at a time, beginning with Noxth Carolina and successively carried to South Carolina, Georgia, and Virginia. The location of areas selected will be plotted on state road maps, because of the scarcity and obsolescence of topographic maps in the southeastern Piedmont.

Two hunared thousand square feet has been chomen tentative as the minimumasize of each area that will be selected, although it is anticipated that slightly smaller areas may be considered localIy. This size has been selected as the minimum for several reasons. Smaller alluvial deposits are generally in fertile tributary valleys. where the value of the land is high enough to deter placer mining. Many of these deposits are of good tenor but if they are mined at all they probably will be mined by the owner, who will need no more encouragement than a few poor crops and a guaranteed price for the monazite. Valley stretches larger than 200,000 square feet are generally of little agricultural value and at the same time they appear to contain tonnage of sufficient size to deserve consideration. 
Thus, a deposit with an area of 200,000 square feet, an average thickness of 10 feet and a tenor of 5 pounds of monazite per cubic yard, would contain about 370,000 pounds of monazite with a gross value of about $\$ 45,000$.

\section{Preliminary field examination}

Upon completing the selection of potentially favorable areas from study of aerial photographs of each state, a field itinerary will be planned to visit each locaisty for a preliminary study, to consist of (1) preparation of a sketoh nap at approximately $1: 20,000$ scale (from radial-line mosaics) showing the outline of alitum course of drainage, and roads; (2) sampling snd panning of samples from riffles, stream cuts, and possjibly a few test pits or auger holes; (3) estimation of approximate average depth to bedrock; (4) determination of kind and proportion of heavy minerals; (5) rough description of land use, volume of water available in the creek, size and type of vegetation covering the placer ground, and size of detritus; and (6) preliminary estimation of volume and tenor.

\section{Exploration}

The data acquired in the first two phases of the work should be adequate to guide physical exploration of promising deposits. Instead of exploring all promising deposits, however, it should suffice to sample in detail only a representative fraction of them. Detailed information obtained on a few deposits likely could be

\section{OFF ICIAL USE ONLY}




\section{OFFICIAI USE ONLY}

31

extrapolated to deposits studied only in reconnaissance for purposes of estimating inferred reserves; such information should also guide and stimulate further exploration by mining companies.

The Geological Survey would like to cooperate with the Bureau of Mines in this phase of the program, and we propose, therefore, the following plan of operation: (1) that the Survey, after study of the reconnaissance data, select specific areas deserving exploration; (2) that the Bureau define ownership and obtain owner permission for physical exploration: (3) that the Bureau handle all engineering phases of exploration, including location and surveying of holes, drilling, and collection of samples, accepting advice from the Survey as to the sample thiclmess; (4) that the Survey anaIyze the samples: (5) that the Survey estimate reserves and report on them; ond (6) that the Burear analyze the setting and reserves of the deposits with a view to selecting those that are minable, and that it also study and report on mining methods. The latter part of proposal (6) is an important part of the work because methods formerly in use in the area were of a primitive type and yet the large scale of placer operation so well developed elsewhere almost certainly will not be applicable in the Southeast.

Although the work of phases one and two probably will not be completed until late in fiscal year 1953, exploration can begin in September 1951 in the vicinity of Shelby, particularly on Knob Creek, where there is about $10,000,000$ square feet of favorable alluvium.

\section{OFF ICIAL USE ONLY}




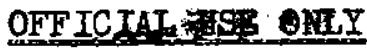

12

CONCLUSIONS

The product of this work would be incorporated in one report which would give: (I) a reconnaissance appraisal of numerous placer sites from Virginia to southerm Georgia including those data outlined above in "Preliminary field examination": (2) results of detailed exploration of selected placers (3) an evaluation of environment and reserves of the western monazite belt based on (1) and (2) above; (4) a review of the special problems in, and most suitable methods for, mining and concentrating monazite; (5) a brief review of land values, mining regulations, and stream pollution ordinances as they affect placer operations throughout the four-state area of the monazite belt. It is expected that parts I, 2 , and 3 would be prepared principally by the Survey and parts 4 and 5 by the Bureau of Mines.

Progress reports will be submitted after the work for each state has been completed. These reports wi.lI include detailed descriptions and maps for each alyurium deposit which will have been investigated. 


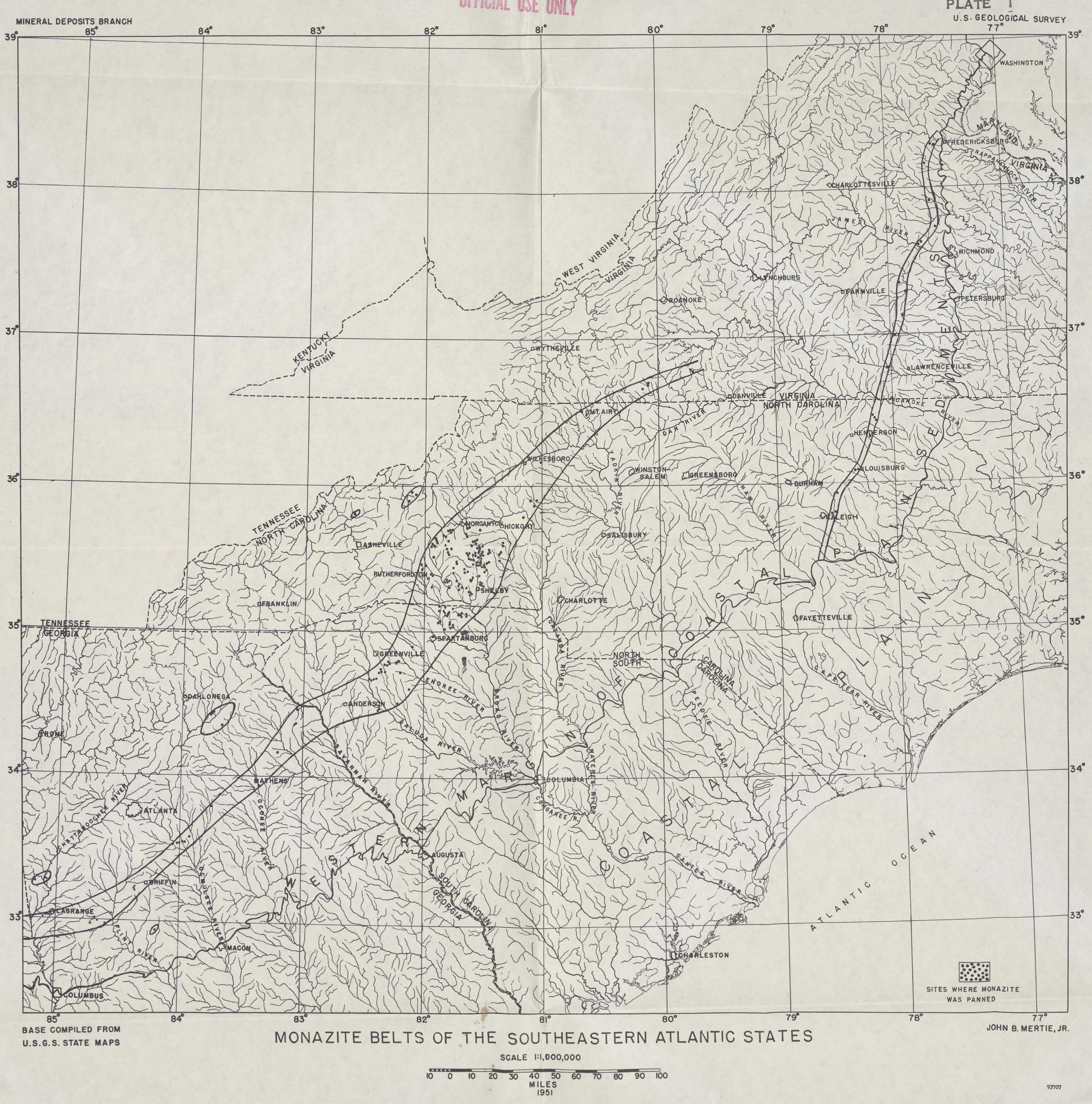

OFFICHAL USE OMU 


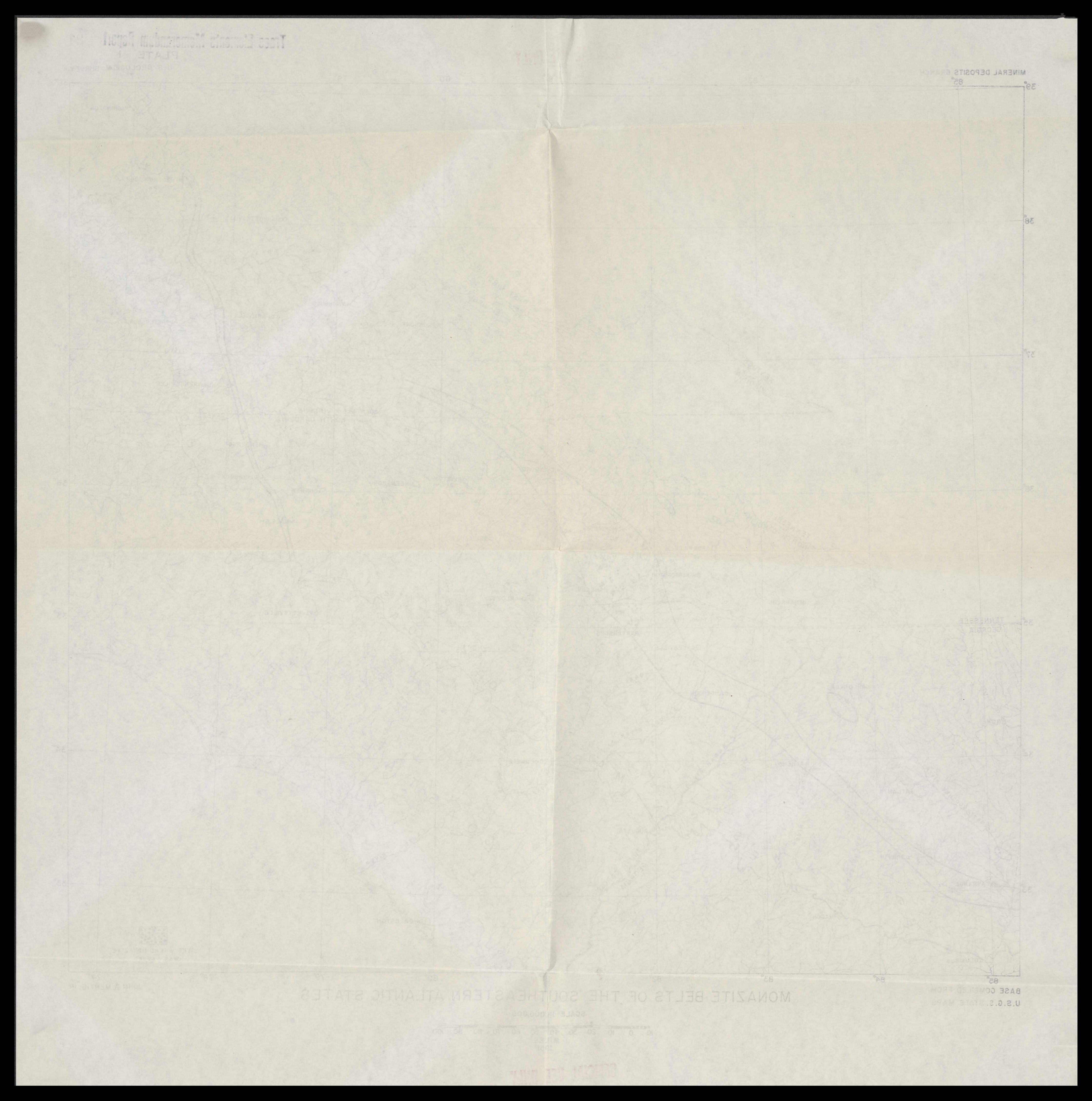



